\title{
Analysis of urban consumer preferences for honey in the context of a transition economy - A case study for Albania
}

\section{Analyse der städtischen Verbraucherpräferenzen für Honig im Kontext einer Transformationsökonomie - Eine Fallstudie für Albanien}

\author{
Alban Cela ${ }^{1}$, Edvin Zhllima ${ }^{1}$, Drini Imami ${ }^{1 *}$, Engjell Skreli ${ }^{1}$, Maurizio Canavari ${ }^{2}$, Catherine Chan $^{3}$
}

\author{
${ }^{1}$ Faculty of Economics and Agribusiness, Agricultural University of Tirana, Albania \\ ${ }^{2}$ Alma Mater Studiorum - University of Bologna, Agricultural Sciences DIPSA, Bologna, Italy \\ ${ }^{3}$ Department of Natural Resources and Environmental Management, University of Hawaii, Mänoa, USA \\ *Corresponding author: dimami@ubt.edu.al
}

Received: 9 September 2019, received in revised form: 22 December 2019, accepted: 27 December 2019

\begin{abstract}
Summary
This paper aims to analyze urban consumer preferences for Albanian honey, focusing on key product attributes such as origin, type, location and price, using a conjoint choice experiment and latent class approach. Origin and location-landscape were found to be the most important factors for most surveyed consumers. Albanian consumers prefer honey produced in mountainous forests and on pastures. Moreover, multi-flower honey is preferred compared to chestnuts honey. These results can be used to producers' advantage when local branding and well-perceived certification (e.g., producer associations' brands) would be applied in order to increase the consumer awareness and strengthen the intrinsic features of the product especially for small producers. Labeling should be clear and emphasize the origin as well as the natural landscape where beehives are kept. Furthermore, in its regionalization economic development policy, the government may consider supporting honey produced from the mountainous areas.
\end{abstract}

Keywords: Consumer preferences, honey, conjoint choice experiment, Albania

\section{Zusammenfassung}

Dieser Artikel analysiert die Präferenzen der albanischen städtischen Verbraucher für Honig, wobei wichtige Produkteigenschaften wie Herkunft, Art, Standort und Preis im Mittelpunkt stehen. Ein Choice-Conjoint-Experiment wurde angewendet, um die Wichtigkeit der Eigenschaften aus KonsumentInnensicht zu ermitteln. Die Herkunft und Standortmerkmale der Landschaft der Honigproduktion haben sich für die meisten befragten KonsumentInnen als der wichtigste Faktor herausgestellt. Die albanischen Verbraucher bevorzugen Honig aus Bergwäldern und von Weidelandschaften. Darüber hinaus wird Blütenhonig gegenüber Kastanienhonig bevorzugt. Diese Ergebnisse können zum Vorteil der Erzeuger genutzt werden, wenn lokales Branding und anerkannte Zertifizierung (z. B. Marken von Erzeugerverbänden) angewendet werden sollten, um das Bewusstsein der Verbraucher zu stärken und die spezifischen Merkmale des Produkts insbesondere für kleine Erzeuger zu stärken. Die Kennzeichnung sollte den Ursprung sowie die natürliche Landschaft, in der die Bienenstöcke gehalten werden, verdeutlichen und hervorheben. Ferner könnte die Regierung in ihrer Regionalisierungspolitik zur wirtschaftlichen Entwicklung erwägen, Honig aus den bergigen Gebieten zu fördern.

Schlagworte: Verbraucherpräferenzen, Honig, diskretes Auswahlexperiment, Albanien 


\section{Introduction}

Beekeeping is an important economic activity in Albanian rural areas. It accounts for the major part of household income for thousands of rural households in Albania. The Albanian Inter-sectorial Strategy for Agriculture and Rural Development 2014-2020 brought attention to the fact that beekeeping could be a highly profitable sector with great development potential (MARDWA, 2014). A recent study considered honey production as a promising activity for farm diversification and sustainable rural development (Zhllima et al., 2016).

The quantity of honey produced in Albania has almost tripled from 2001 to 2015 . However, honey trade is very small with some years of zero exports, and the import is about $1 \%$ of the domestic production and consumption (Table 1). At the present, the opportunity to export Albanian honey is limited, because the production and distribution are fragmented while the product does not meet the (standards) requirements of the EU market. Thus, the domestic market demand is the only driving force behind the increase of the domestic production.

Zhllima et al. (2016) and Imami et al. (2015) found that added-value honey from Albania such as chestnut honey has a market potential both in the domestic market as well as in ethnic (niche) markets abroad (Albanian diaspora). Interestingly, chestnuts and chestnut honey were among the first geographical indications (GIs) formally registered in Albania. At present, chestnut (mainly found in forests) and chestnut honey from Tropojë and Rec have four separate registered GIs in Albania (of the eight existing GIs) (Bernardoni et al., 2018).

Honey production is performed throughout Albania. The honey production per capita is high in the regions of Korçë, Vlorë, Kukës, and Gjirokastër. Among these regions, the honey production in kg per capita in 2015 was
3.2 in Korçë, 2.8 in Vlorë, 2.5 in Kukës, 1.9 in Gjirokastër, 1.3 in Berat, 1.2 in Fier and Shkodër, 1.0 in Elbasan, and below 1.0 in other regions (INSTAT, 2016). Korçë has the highest number of beehives, making up $18 \%$ of the total production in Albania. The regions of Vlorë and Gjirokastër, representing a common area named as Labëria, are surrounded by a high diversity of plants that makes their honey distinct from other areas. Also, in Kukës, which is the third in terms of honey per capita production, beehives are surrounded by a diversity of flowering plants and chestnut trees, especially in the mountainous areas of Tropojë. Furthermore, these regions have a strong tradition in honey production (Ajazi and Tabaku, 2015).

Thus, in line with the production potential and tradition, this study focuses on honey produced from the regions of Korçë (situated in southeast of Albania), Labëria (combined regions of Gjirokastër and Vlorë in southwest Albania), and Tropojë (in Kukës region which is in the northeast Albania). These regions are distinct from each other and represent three different areas of Albania where the main differences are their landscape (eg. being mountainous) and the number of farmers engaged in beekeeping activity. As the production origin is of paramount importance for the determination of intrinsic values of honey, scrutinizing the preferences for these three regions may create informative conclusions for the marketing strategies to be pursued by farmers of these regions.

There are different marketing channels for honey. Few larger (whose main farm activity is honey production) beekeepers supply their products to supermarkets and small shops in the main cities of Albania, as well as directly to restaurants. However, direct sales to consumers is more common, similar to olive oil (Imami et al., 2013). Honey is often labeled based on the plants or trees from which the nectar comes and is priced accordingly; for example, chestnut honey is often labeled and marketed and charged

Table 1. Main indicators for honey production sector in 2001-2015

Tabelle 1. Hauptindikatoren des Sektors der Honigproduktion in den Jahren 2001-2005

\begin{tabular}{lrrrrrrrr}
\hline Category & 2001 & 2005 & 2010 & 2011 & 2012 & 2013 & 2014 & 2015 \\
\hline Production (t) & 1,183 & 1,816 & 2,886 & 2,898 & 3,000 & 3,000 & 3,000 & 3,200 \\
Import (t) & 16 & 42 & 24 & 21 & 34 & 28 & 32 & 33 \\
Export (t) & 0 & 0 & 10 & 20 & 10 & 13 & 0 & 0 \\
Domestic supply (t) & 1,199 & 1,858 & 2,900 & 2,899 & 3,024 & 3,015 & 3,032 & 3,233 \\
Import/supply (\%) & 1.3 & 2.3 & 0.8 & 0.7 & 1.1 & 0.9 & 1.0 & 1.0 \\
Export/production (\%) & 0.0 & 0.0 & 0.3 & 0.7 & 0.3 & 0.4 & 0.0 & 0.0 \\
\hline
\end{tabular}

Source: INSTAT (2016) for Production and UNSTAT for Trade Data (2016). 
with higher prices (when compared to other honey). Such labeling is typically performed by producers without any regulation or control from any public or private body.

As highlighted above, the domestic market demand has been and is expected to be the main driving force for domestic production. In this context, understanding local consumer preferences for various honey attributes is instrumental in designing efficient and sustainable marketing strategies for private entrepreneurs interested in supplying and selling the honey.

The purpose of the survey is to assess Albanian urban consumer preferences for the main attributes of honey, such as production origin, location/landscape (which is related to feeding system), pollination plant, and price. The findings may serve as a basis to develop production and marketing positioning strategies as well as to develop policies related to territorial certification and promotion.

\section{Literature review}

There is a growing literature on consumer preferences for honey. Several articles highlight the importance of price among other attributes such as quality, flavor and texture. Murphy et al. (2000), by using a conjoint analysis, showed that for the surveyed consumers the most important honey attributes are price and texture, followed by packaging, the scale of production (small vs. mass production), and color. Also Šánová et al. (2017) confirmed that price is one of the main attributes among Czech consumers. Kos Skubic et al. (2018) found that, in Slovenia, consumer's most important attribute is price and the least important is the label of origin.

Pocol and Mărghitaş (2007) in Romania, Arvanitoyannis and Krystallis (2006) in Greece, and Brščić et al. (2017) in Croatia found that honey reflects dimensions that are not related to simple food, such as healthy, dietary, and medicinal benefits. Similarly, Yeow et al. (2013) found that medical condition, quality of the product, brand reputation, and pricing do influence the purchase intentions. Also, for the Polish consumers, health benefit is perceived as a major incentive for honey consumption (Kowalczuk et al., 2017).

Juma et al. (2016) found a higher preference of consumers for thick honey compared with loose honey, as Kenyan consumers perceive the viscosity related to the medicinal use of honey. On the basis of a student's survey, Pidek (2001) found that students preferred liquid honey (versus crystallized) and light-colored honey (versus darker one), and the multi-flowered pollinated one was the most preferred type. Ghorbani and Khajehroshanaee (2009), using the hedonic pricing model and cross-sectional data from a consumer sample, found that the type of honey as well as its processing conditions, color, aroma, and protraction are important attributes.

Some authors have focused on the floral source of the honey. The floral source conveys the information on the type of plants, which influences the quality of honey (Kaškoniené and Venskutonis, 2010) and is expected to influence the consumer preferences. For instance, Thrasivoulou et al. (2000), using an existing sensory test of honey quality, found that pine, thyme, and chestnut honey were most preferred. Gyau et al. (2014), analyzing preferences of Democratic Republic of Congo consumers, showed that consumers have a strong preference for local forest and savannah landscape honey.

Another important attribute is the origin of production. Šánová et al. (2017) confirmed that origin is one of the main attributes for honey consumers. Geographic location of the honey's production is considered important among US consumers (Wu et al., 2015). In Europe, quality labels (such as protected designation of origin [PDO]) are perceived important for assuring quality (Brščić et al., 2017; Kos Skubic et al., 2018). Also, Cosmina et al. (2016) found that local origin, which is related to the habitat, is important to consumers. Moreover, they found that in addition to the country of origin (domestic honey was preferred for which willingness to pay was higher), the "organic" attribute was important for consumers. Indeed, organic attribute was found to be very important among Albanian consumers for other agrifood products (Imami et al., 2017; Skreli et al., 2017).

Other attributes identified in previous studies are packaging and brand. Ványi et al. (2011) have identified that Hungarian consumers appreciate quality of packaging, in addition to the type of honey. Batt and Liu (2012) identified brand reputation and the best value for money as the most important attributes.

The sociodemographic analyses on studying consumer preferences for honey are of strong importance for marketing policies. Pocol and Mărghitaş (2007) found that persons with higher consumption of honey are more educated and with higher incomes compared to others. Ványi et al. (2011) emphasized that older people take into consideration mainly the price, the producer's name, and size of packaging. Ćirić et al. (2015) emphasized that older people (aged $>50$ years) 
are more loyal and that the more educated are those who dominate the share of the honey consumers. Honey consumers are also more oriented to healthy food and physical activities such as sports. Juma et al. (2016) identified that consumers who have a strong preference for organic honey are the middle-income consumers and seniors.

There have been no in-depth studies focused on the consumer preferences for honey in Albania before this survey was designed, according to the best of authors' knowledge. Despite the high importance of honey for smallholders in remote rural areas in terms of diversification and revenues, no prior study has been focusing on revealing Albanian consumer preferences for honey attributes. The study was enabled in the framework of action research conducted with an association of farmers in northeast Albania named ADAD Malore with the support of Empowering Smallholder Farmers in Markets (EFSIM) whose purpose was to support the honey sector based on research evidence.

\section{Methodology}

The conjoint analysis derives from the theoretical basis established by Lancaster (1966, in: Mtimet et al., 2008) according to which the utility of a product is based on the bundle of attributes it has. Conjoint choice experiment (CCE) was developed by Louviere and Woodworth (1983) and was originally used in the market research in addition to other fields of research (Hensher, 1994). CCE has been widely used to analyze consumers' behavior in Albania (Chan-Halbrendt et al., 2010; Zhllima et al., 2012; Skreli et al., 2017) as well as in other countries in the region such as Kosovo (Bytyqi et al., 2015).

According to Lancaster (1966), the utility of any good is derived from the characteristics (attributes) of the good rather than the good itself. The CCE approach is based on the idea that a good can be described by its attributes and by their levels. As shown in Table 2, there are five stages for developing a CCE before collecting data and conducting analysis (Green 1975; Cattin and Wittink, 1982; Halbrendt et al., 1991).

The first stage of CCE is to determine the attributes, and the second stage is to specify attribute levels. Different studies have used various techniques for determining the most relevant product attributes such as focus groups or in-depth interviews.

In order to select the attributes for honey in exploring consumer preferences in Albania, the authors have made use of literature review and focus groups with the members of the Association of Honey Producers in Kukës from the northeast of Albania and other stakeholders to assist in designing the survey. The CCE was carried out in two stages, wherein the first stage was to determine the specific attributes, and the second stage was to determine the attribute levels.

The authors made an initial identification of potential attributes based on the literature review ${ }^{1}$ and then coordinated the first focus group of honey producers and other stakeholders from Kukës region to select the most important honey attributes (stage I of the CCE). The group for determining the attributes was composed of 1 veterinarian, 1 agricultural economist, as well as 14 beekeepers originating from Kukës and Tropojë. The main types of honey that the beekeepers produce are the multi-flower and chestnut honey. On the other hand, there was carried a rapid appraisal of the market of Tirana and Durrës, the two largest cities and markets in Albania, to assess specific attribute levels (such as prices).

The production origin of the honey was found as very important from the focus group. The statistics of production shown in the introduction section highlight the importance of specific regions of honey production, namely, Korçë (which is the first region of importance in terms of production per capita and number of beehives), Labëria (where the regions of Vlorë and Gjirokastër are included), and Tropojë (which is a well-known mountainous subregion of Kukës).

The focus groups chose location-landscape type as another very important attribute, because it is related to the feeding system. According to the participants, the location of the beehives near to natural landscapes such as mountainous forests and pastures is a very important attribute. Cosmina et al. (2016) used pictures in order to illustrate the location-landscape attribute to the surveyed consumers. Previous studies on consumer preferences have shown that the Albanian consumers have a strong preference for products from specific territories within the country, including honey (Imami et al., 2015). Moreover, differently from all the previous studies, we use both specific local origin and beehives habitat/landscape as two different attributes.

The floral pollination source is also important and has been a focus of some studies in other countries (Pidek, 2001). Again, there are no studies exploring Albanian consumers'

\footnotetext{
Such as Murphy et al., 2000; Pidek, 2001; Arvanitoyannis and Krystallis, 2006; Pocol and Mărghitaş, 2007; Ghorbani and Khajehroshanaee, 2009; Batt and Liu, 2012; Gyau et al., 2014; Cosmina et al., 2016 - for more details see the previous section.
} 
Table 2. Stages of a conjoint choice experiment and analysis carried for honey

Tabelle 2. Phasen eines diskretes Auswahlexperiments und einer Analyse für Honig

\begin{tabular}{ll}
\hline Stage & Description \\
\hline Selection of attributes & Attributes were selected based on a focus group with stakeholders in the honey sector and an extensive literature review. \\
Assignment of attribute levels & $\begin{array}{l}\text { Attribute levels were determined based on the literature review and a (second) focus group comprised of stakeholders in the } \\
\text { honey sector. }\end{array}$ \\
Construction of choice sets & $\begin{array}{l}\text { The SSI Web program using the random method that incorporated orthogonal array was used to create the profiles in the survey. } \\
\text { Data collection }\end{array}$ \\
The survey was conducted via face-to-face interviews.
\end{tabular}

Source: Chan-Halbrendt et al. (2010)

preference for the type of honey based on the type of floral pollination; however, in the focus group, participants found this attribute important referring particularly to multiflower and chestnuts honey. Chestnuts and chestnut honey were among the first geographical indications (GIs) formally registered in Albania (Bernardoni et al., 2018).

As a result, four attributes were chosen for this study: (1) origin, (2) type of honey, (3) location-landscape of the beehives (which is related to feeding system), and (4) price (Table 3). For each attribute, respective levels were chosen based on the literature review and on the findings from another focus group that was composed of two marketing experts, two veterinarians, four beekeepers originating from Labëria and Tropojë, as well as one food processing technician.

The third stage of designing the CCE involves the construction of choice sets. Honey product profiles were constructed by selecting one level from each attribute and combining across all attributes. In this study, there are four attributes, of which one has four levels (price), two have three levels, and one has two levels. Randomized design (complete enumeration option of Sawtooth Software SSI Web version 6.6) was used for generating the choice tasks.

Table 3. Honey attributes and their levels in Albania

Tabelle 3. Eigenschaften von Honig und deren Level in Albanien

\begin{tabular}{llll}
\hline Attributes & Levels & & \\
\hline Origin & Tropojë & Korçë & Labëria \\
Type & Chestnuts type & Multi-flower type & Multi-flower type \\
$\begin{array}{l}\text { Location- } \\
\text { landscape }\end{array}$ & $\begin{array}{l}\text { Close to } \\
\text { residential areas }\end{array}$ & $\begin{array}{l}\text { In mountainous } \\
\text { forests and pastures }\end{array}$ & $\begin{array}{l}\text { Close to } \\
\text { residential areas }\end{array}$ \\
$\begin{array}{l}\text { Price } \\
(\text { ALL }\end{array}$ & 1000 & 1300 & 1600
\end{tabular}

Source: Authors elaborations. In Labëria, consumers perceive beekeepers who produce honey in mountainous area of Gjirokaster, Vlorë, Tepelene, and Saranda. Consumers were shown the pictures regarding the attribute description for a better perception. ALL = Albanian Lek (1 EUR = 122 ALL).
In complete enumeration, profiles are nearly as orthogonal as possible within respondents, and each two-way frequency of level combinations between attributes is equally balanced. Within choice sets, attribute levels are duplicated as little as possible (a property called "minimal overlap" (Chrzan and Orme, 2000)).

Twelve choice tasks of triple concepts were included in each questionnaire, and each respondent was asked to choose 12 concepts, one for each triple choice tasks; a "none" option was also included in each concept. Seven questionnaire versions were generated, which make possible the inclusion in the questionnaire of 84 choice tasks and 252 concepts of 4 attributes each. The design was tested for efficiency. As the efficiency for production mode and origin resulted lower than $99 \%$, an advanced test was conducted, and the p-value for all variables and attributes resulted lower than 0.05 , meaning that the design is optimal or efficient.

The fourth stage was data collection. For each of the seven versions of the survey, there were two parts. The first part consisted of choosing the 12 choice tasks (Table 4), and the second part included additional questions on sociodemographic details of each respondent (such as age, education, and income), and several questions were included to obtain insight into consumer purchasing and consumption habits.

In our study, we followed the approach of Cosmina et al. (2016) who used pictures in order to illustrate the location-landscape attribute showing mountainous versus residential settings.

As for the fifth stage, the choice-based conjoint data generated with this experiment have been analyzed using Life Cycle Assessment (LCA). This method uses choice data for the simultaneous development of segments and estimation of part-worth utilities for the attributes and levels included in the design. For each respondent in the sample, a probability of belonging to each segment (class) is estimated. 
Table 4. Example of a choice task

Tabelle 4. Beispiel einer Auswahlaufgabe

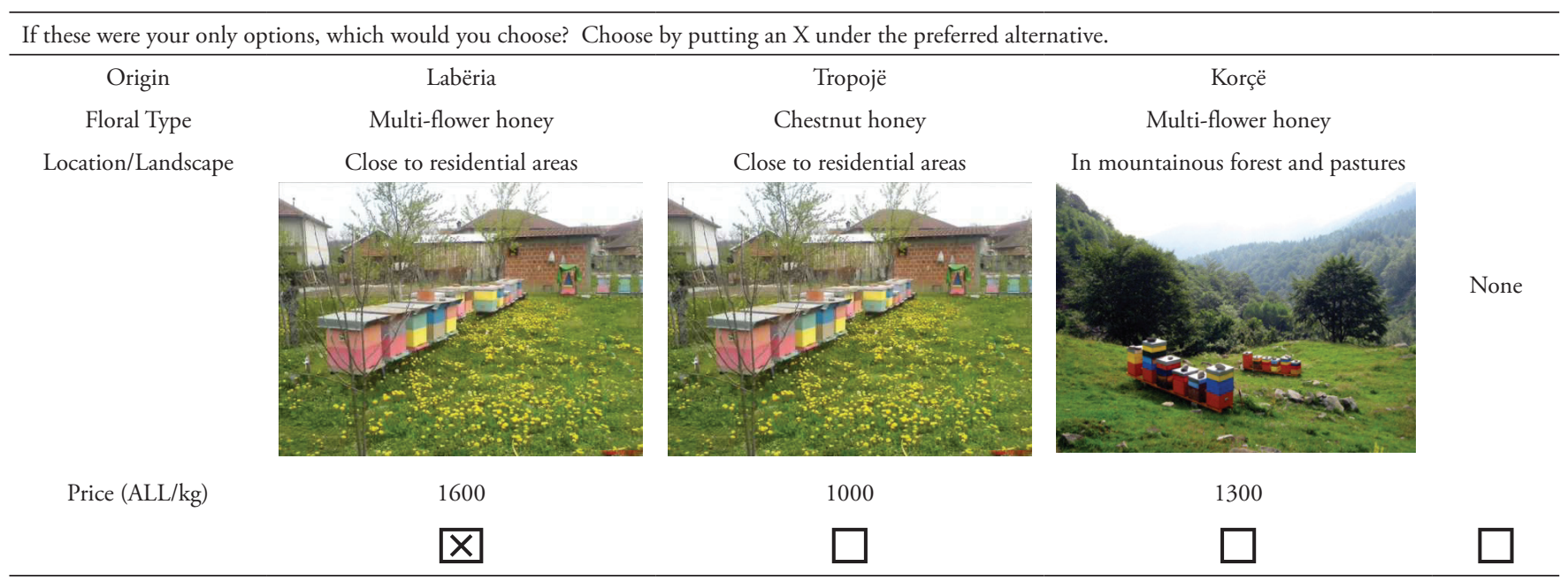

Source: Authors elaborations.

Therefore, they are not classified into a specific segment univocally, as it is usual in cluster analysis.

A total of 250 face-to-face interviews were carried out in Tirana using random choice approach. Interviews were conducted by four trained interviewers (students and alumni) supervised by the authors of this article. The interviews took place during November and December 2016. Tirana is the capital city and largest city in the country and offers the advantage of diversity of respondents in terms of culture, religion, and income levels. It is expected that an important target market for honey will be Tirana (capital city), given the size of the population and the higher average income that characterizes it. The interviews took place in various parts of Tirana (which were determined in advance based on an expert assessment). People were approached as follows: after completing each face-to-face interview, interviewers approached the next closest person who walked by.
The average age of the respondent was 44 years. The sample was divided quite symmetrically by gender $(51 \%$ are men). The vast majority ( $94 \%$ of the respondents) were from urban areas of Tirana. Age distribution of the sample is reflected and compared with Tirana urban population age structure (Table 5). Slight differences were found in the representation of the consumers' age groups with an exception of more than 60 years age group. The underrepresentation of this age group was related to the upper boundary $(>70)$, which were less frequent compared to other age groups in the public areas.

A sociodemographic analysis has been carried out for each selected class. Cross tabulation of main sociodemographic variables, namely, gender, age, education, employment status, and incomes, has been made. A chi-square test with adjusted residuals was used to understand the class composition. The procedure to understand what cells caused the

Table 5. Comparison of the age structure of the survey respondents and the urban population of Tirana, 2011

Tabelle 5. Altersstruktur der Stichprobe und der gesamten Stadtbevölkerung von Tirana, 2011

\begin{tabular}{cccc}
\hline Age Category (Years) & Frequency & Sample Structure (\%) & Tirana Population Structure (\%) \\
\hline $18-30$ & 58 & 23.2 & 19.2 \\
$30-40$ & 49 & 19.6 & 18.2 \\
$40-50$ & 49 & 19.6 & 18.9 \\
$50-60$ & 59 & 23.6 & 21.8 \\
More than 60 & 35 & 14.0 & 22.7 \\
Total & 250 & 100.0 & 100.0 \\
\hline
\end{tabular}

Source: Field survey and INSTAT (2012). 
Table 6. Summary statistics of latent class analysis of honey preferences of respondents by group

Tabelle 6. Zusammenfassende Statistik der Befragten nach Gruppen

\begin{tabular}{llllll}
\hline Groups & Replication & Pct Cert & CAIC & Chi Square & Rel Chi Sq \\
\hline 2 & 4 & 31.82 & 5788.18 & 2646.67 & 203.59 \\
3 & 1 & 37.98 & 5338.84 & 3159.05 & 157.95 \\
4 & 42.76 & 5003.86 & 3557.08 & 131.74 \\
5 & 4 & 45.95 & 4801.66 & 3822.32 & 112.42 \\
\hline
\end{tabular}

significance went through three steps, which were given as follows: (i) adjusted residuals were saved when the cross tabulation was conducted and transferred from SPSS to excel; (ii) following the Bonferroni correction test, a new p-value was calculated by dividing the standard p-value $(0.05)$ with the number of cells for each cross tabulation (e.g., for gender, the resulting p-value of 0.006 is the ratio of standard $\mathrm{p}$-value and 8 is the number of cells ( 4 rows multiplied by 2 columns); (iii) using excel NORMSINV function, a new z critical value corresponding to the new p-value is calculated and the $\mathrm{z}$-value for the $\mathrm{p}=0.006$ is -2.73 ; (iv) the cells causing the significance were identified and highlighted in bold by comparing the adjusted residuals with the new z-value calculated-the cells with adjusted residuals greater than $|z|$ are marked with one star and adjusted residuals less than z-value are marked with two stars.

\section{Results}

Latent Class Analysis enables the segmentation of consumer sample into separate classes following several replications. The division in four classes was deemed proper considering the relative change in consistent Akaike information criterion and the chi-square and also considering the recent development of the honey market in Albania (Table 6).

Table 7. Market segmentation for honey

Tabelle 7. Marktsegmentierung für Honig

\begin{tabular}{|c|c|c|c|c|}
\hline \multirow[t]{2}{*}{ Segment size (\%) } & $\begin{array}{r}\text { Class } 1 \\
\text { Multi-flower }\end{array}$ & $\begin{array}{l}\text { Class 2 } \\
\text { Quality }\end{array}$ & $\begin{array}{r}\text { Class } 3 \\
\text { Mountainous } \\
\text { Tropojë fans }\end{array}$ & $\begin{array}{r}\text { Class } 4 \\
\text { Economic }\end{array}$ \\
\hline & 26.7 & 19.2 & 15.7 & 38.4 \\
\hline \multicolumn{5}{|l|}{ Importance of attributes (\%) } \\
\hline Origin & 23.1 & 7.8 & 77.2 & 44.2 \\
\hline Type & 6.7 & 36.2 & 4.8 & 12.3 \\
\hline Location & 66.8 & 5.2 & 12.9 & 3.5 \\
\hline Price & 3.4 & 50.8 & 5.1 & 40.0 \\
\hline \multicolumn{5}{|l|}{ Part Worth Utility } \\
\hline \multicolumn{5}{|l|}{ Origin } \\
\hline Tropojë & $0.56349^{* * *}$ & $0.14887^{* *}$ & $3.13669^{* * *}$ & $-0.34951^{* * *}$ \\
\hline Korçë & -0.04972 & 0.08934 & $-1.83438^{* * *}$ & $0.44005^{* * *}$ \\
\hline Labëria & $-0.51377^{* * *}$ & $-0.23821^{* * *}$ & $-1.30231^{* * *}$ & $-0.09054^{* *}$ \\
\hline \multicolumn{5}{|l|}{ Type } \\
\hline Chestnuts type & $-0.15603^{* *}$ & $-0.89917^{* * *}$ & 0.15208 & $0.11046^{* * *}$ \\
\hline Multi-flower type & $0.15603^{* *}$ & $0.89917^{* * *}$ & -0.15208 & $-0.11046^{* * *}$ \\
\hline \multicolumn{5}{|l|}{ Location-landscape } \\
\hline Near to residential areas & $-1.55979^{* * *}$ & $-0.12875^{* *}$ & $-0.41545^{* *}$ & -0.03107 \\
\hline In mountainous forests and pastures & $1.55979^{* * *}$ & $0.12875^{* *}$ & $0.41545^{* *}$ & 0.03107 \\
\hline Price & 0.0801 & $1.26277^{* * *}$ & 0.16705 & -0.35738 \\
\hline None of the Options & $-37.3058^{* * *}$ & $-4.76935^{* * *}$ & $-1.29179^{* * *}$ & $-5.11288^{* * *}$ \\
\hline
\end{tabular}

Source: Authors contribution. ${ }^{* *}=0.01$ of significance $(\mathrm{T}$ absolute values $>2.6) .{ }^{* *}=0.05$ of significance $(\mathrm{T}$ absolute values $1.96</ \mathrm{t} /<2.6)$. 
Table 8. Class composition of respondents

Tabelle 8. Klassenaufbau der Befragten

\begin{tabular}{|c|c|c|c|c|c|c|c|c|c|c|c|c|c|c|c|c|c|c|c|c|c|}
\hline \multirow{2}{*}{$\begin{array}{l}\text { Consumer } \\
\text { Class }\end{array}$} & \multicolumn{2}{|c|}{ Gender } & \multicolumn{5}{|c|}{ Age (Years) } & \multicolumn{3}{|c|}{ Education } & \multicolumn{5}{|c|}{ Employment Status } & \multicolumn{6}{|c|}{ Family Monthly Income (000 ALL) } \\
\hline & $\sum^{\tilde{\Xi}}$ & 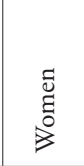 & 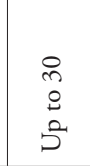 & $\begin{array}{l}\stackrel{+}{+} \\
\text { o }\end{array}$ & i̊ & $\begin{array}{l}0 \\
0 \\
1 \\
1\end{array}$ & 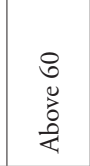 & 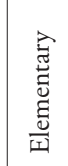 & 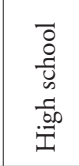 & 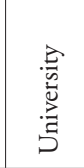 & 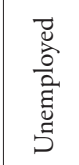 & $\begin{array}{l}\vec{E} \\
\frac{\vec{E}}{E} \\
\text { D }\end{array}$ & 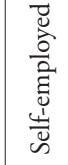 & 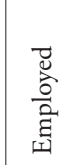 & 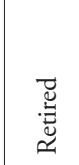 & $\begin{array}{l}8 \\
\text { 1े } \\
0\end{array}$ & $\begin{array}{l}8 \\
0 \\
1 \\
1 \\
0 \\
\infty\end{array}$ & $\frac{8}{\stackrel{\circ}{1}}$ & 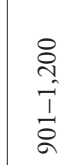 & 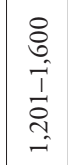 & $\begin{array}{l}8 \\
8 \\
i \\
i \\
0 \\
0 \\
0\end{array}$ \\
\hline $\begin{array}{l}\text { Multi-flower } \\
\text { honey fans }\end{array}$ & $-4.2^{* *}$ & $4.2^{*}$ & 2.5 & 1.9 & -4.1 & -1.8 & 1.6 & 1.2 & $-5.0^{* *}$ & $3.8^{*}$ & 2.7 & 0.6 & -0.4 & -5.0 & 2.1 & 2.6 & $-3.8^{* *}$ & 2.6 & $-3.9^{* *}$ & 1.8 & 0.7 \\
\hline $\begin{array}{l}\text { Quality } \\
\text { oriented class }\end{array}$ & -2.3 & 2.3 & 0.1 & 1.8 & $4.8^{*}$ & -2.1 & $-4.6^{* *}$ & -2.5 & -0.1 & 2.5 & $-5.5^{* *}$ & 2.2 & 0.5 & $5.9^{*}$ & $-3.1^{* *}$ & -1.7 & -2.0 & $-4.1^{* *}$ & $6.0^{*}$ & 0.7 & 1.1 \\
\hline $\begin{array}{l}\text { Mountainous } \\
\text { Tropojë fans }\end{array}$ & $3.7^{*}$ & $-3.7^{* *}$ & 1.0 & -2.6 & -1.6 & 2.8 & 0.5 & -1.5 & -0.5 & 2.0 & 0.5 & 0.9 & 2.3 & -2.2 & -1.4 & -0.4 & $-4.3^{* *}$ & $6.8^{*}$ & -0.5 & -0.9 & -0.8 \\
\hline $\begin{array}{l}\text { Chestnuts } \\
\text { Korçë fans }\end{array}$ & $2.9^{*}$ & $-2.9^{* *}$ & $-3.5^{* *}$ & -1.0 & 1.0 & 1.1 & 2.4 & 2.7 & $5.5^{*}$ & $-8.3^{* *}$ & 2.3 & $-3.8^{* *}$ & -2.3 & 1.3 & 2.5 & -0.5 & $10.0^{*}$ & $-5.3^{* *}$ & -1.6 & -1.7 & -0.9 \\
\hline & $\mathrm{p}$ & 0.006 & & & $\mathrm{p}$ & 0.003 & & & $\mathrm{p}$ & 0.004 & & & $\mathrm{p}$ & 0.003 & & & & & $\mathrm{p}$ & 0.002 & \\
\hline & $\mathrm{z}$ & -2.73 & & & $\mathrm{z}$ & -3.02 & & & $\mathrm{z}$ & -2.87 & & & $\mathrm{z}$ & -3.02 & & & & & $\mathrm{z}$ & -3.08 & \\
\hline
\end{tabular}

Source: Authors contribution.

${ }^{*}$ Adjusted residuals greater than $|\mathrm{z}|$.

** Adjusted residuals less than z.

The largest class was class 4 , which covered $38.4 \%$ of the sample (Table 7). For this class, the most important attribute was origin and price, followed by type and location. This class showed a high preference for honey from Korçë, pollinated from chestnut trees while maintaining preferences for low price honey. The location landscape attribute was not significant, although the consumers preferred honey from mountainous forests and pastures. This class can be named as "Economic class."

The second largest class was class 1 . Consumers of this class perceived that the most important attribute was landscape followed by origin. This class strongly preferred honey from mountain forests and pastures of Tropojë. The type preferred by this class is the multi-flower. Moreover, this class seemed to be price insensitive, although this attribute was not statistically significant. This class can be named as "Multi-flowers class."

For class 2, the most important attribute was price. Interestingly, there was a positive sign: consumers preferred more expensive honey to the cheaper one. That implied that a high price is perceived as a proxy for quality. The second most important attribute was type, there is a strong preference for multi-flower honey from mountainous areas of Tropojë while disregarding the honey from Labëria (provided that it is available at any price (within the 1000-
1,750 ALL/kg price range)). This class can be named as "Quality class."

The smallest class in terms of size was class 3. The consumers of this class gave high importance to origin and location of the beekeeping activity. They preferred honey from mountainous forests and pastures from Tropojë. The price and type of honey were not statistically significant. This class can be named as "Mountainous Tropojë class."

A sociodemographic analysis has been carried for each selected class. A chi-square test with adjusted residuals was used to understand the class composition. It comes out that in "multi-flower" class, we find more high-educated women (highlighted in bold and assigned with one star in Table 8). In the "quality" class, we find more employed middle age, mid-income consumers. Men dominate the "mountainous Tropojë fans" class and "Chestnuts Korçë fans" segments.

\section{Discussion and Conclusions}

This study is the first in-depth consumer research focused on honey in Albania. The study throws light into various important aspects of mainly urban consumer preferences for honey attributes including origin, type, location, and price. 
Origin is one of the most important attributes for two of the four consumer's classes and the most important attribute for the largest consumer segment. Most consumers prefer the multi-flower honey, although $38 \%$ prefer chestnut honey. All the consumer classes unanimously prefer honey produced in mountainous forests and pastures. This means that the landscape where beehives are surrounded by mountainous forests and pastures is important from consumer's perspective to ensure the quality and medicinal properties of honey. This finding is useful for producers in mountainous areas who aim at the production and sale of honey as a niche market product. Effective promotion that transmit essential signals for the consumers as to the honey's production habitat and other intrinsic factor related to the image of location and type of beekeeping will result in higher sales and prices. Thus, integrating origin and location values into their brand can enhance the production and increase revenues.

Three of the four classes of consumers are not price sensitive, except for class 2 . Interestingly, the price parameter is positive and significant for class 2 , indicating that consumers prefer more expensive honey to the cheaper one. This implies that for this group, a high price is perceived as a proxy for overall quality. Indeed, consumers often associate higher prices with better quality (Völckner and Hofmann, 2007). Also, Judd (2000) explained that consumers seeking value, in cases when they cannot assess the quality based on intrinsic clues, view price as a distinctive indicator for quality. The perceived quality associated with a price may spur people to choose higher-priced food products, especially in countries with a weak institutional framework in terms of food safety and quality standards control, such as the case of Albania. Previous studies on olive oil (Chan-Halbrendt et al., 2010) and wine (Zhllima et al., 2012) in Albania have similar findings (some consumer groups prefer more expensive products). Also studies on Italian consumer preferences for olive oil highlight that price has a significant influence on the consumer choices (Cicia et al., 2002; Scarpa and Del Giudice, 2004). This high interest in quality as shown through pricing may motivate both producers and public authorities to invest in improving a quality assurance system. Furthermore, in its regionalization economic development policy, the government may consider supporting honey produced from the mountainous chestnut areas. Considering that many consumers purchase honey regularly, price is an important factor, especially among lowincome consumer groups. Therefore, if there are price differences between branded and the generic honey sold in the supermarket, the higher-priced product should be associated with better marketing and communication to consumers. In this context, the calculation of willingness to pay for honey that has specific attributes may be considered in future research work.

A sociodemographic analysis has been carried out for each selected class. The significance of sociodemographic variables differs from those identified from Pocol and Mărghitaş (2007), Ćirić et al. (2015), and Juma et al. (2016). The "multi-flower honey" preference group are mainly women and highly educated, so products of this nature should be sold in outlets where highly educated women do shopping including also online outlets. The "quality" class are middle-aged and employed with medium-income consumers. This segment of consumers is oriented toward multi-flower honey. Charging the appropriate price to indicate quality is important, given the share of importance and significance for this market segment. The consumer's ability to absorb an increasing price of honey, as witnessed during the recent decade in Albania because of increasing income should be an indication for optimism for raising prices.

The class 3 named "mountainous/Tropojë fans" reveals a predominance of men, with low-medium household incomes. This class is very much likely to be a target as an ethnicity market (niche) segment because they highly value the attributes origin and location. These attributes should be highlighted when designing the promotional campaigns and the branding image.

The fourth class, "economic" class whose consumers prefer chestnuts honey from Korçë are mainly men with relatively low incomes. This is the largest category of consumers, who represent a modest level of education and incomes, where origin and price have the highest importance. Promotion of local production based on the specific quality while maintaining a reasonable price would create high demand in this market segment.

The survey targeted urban consumers (even though they make up almost half of the Albanian population) who may have different consumption pattern when compared to rural consumers. The conclusions provided for the urban residents of Tirana are still important because it is the most important market in terms of size and purchasing power. Furthermore, it can also be considered as indicative information for other urban areas that, despite important differences, have similarity in terms of culture.

The evidence of the study shed lights also on the policymaker's agenda. In order to promote smallholder operators from mountainous areas, massive promotion campaigns 
should be organized. The use of origin and other intrinsic values related to location and production methods would strongly influence not only honey producers but also the tourism activities in these areas because consumers become aware of the healthy environment and natural richness.

As the honey market is developed under a weak institutional structure, credible local branding and well-perceived certification should be applied in order to increase the consumer awareness and strengthen the intrinsic features of the product especially for small producers. Labeling should be clear and emphasize the origin as well as the natural landscape where beehives are kept, following the example of the EU quality schemes and certification (GIs) that were established to provide trust and protect consumers from falsification and, at the same time, to protect also local producers. Moreover, price segmentation should differentiate the honey from mountainous areas, certified and labeled in a way to promote the quality and health benefits.

The price stability factor is also an essential element to be safeguarded by the policymakers. The price increase trend reflects that the market has relatively few industrial players and the majority of the product is based on smallholders. However, the trust toward producers is the key to real price perceived by consumers. Policymakers should stimulate collective action in the beekeeping sector, in order to facilitate the creation of strong product network sales, where common branding and sale based on associative entities would increase the honey quality and strengthen consumer trust. The study provides food for thought for the research community. Additional attributes and methods should be considered in the future such as sensory tests. Modeling the honey marketing actions on socioeconomic segmentation is not the best strategy if honey producers do not adjust their production and sales strategy based on the information on purchasing behaviors. The evidence from consumer preferences surveys in the future should be transmitted to producers' lenses through continuing action research. This requires a more sustainable system of observation in the market based on a close university-business partnership to reduce myopia for designing marketing activities and programs.

\section{References}

Ajazi, N. and V. Tabaku (2015): The cultivation of chestnut, in Dibra, Kukës and Tropojë district in Albania. International Journal of Agriculture Innovations and Research 3, 1401-1406.
Arvanitoyannis, I. and A. Krystallis (2006): An empirical examination of the determinants of honey consumption in Romania. International Journal of Food Science \& Technology 41, 1164-1176.

Batt, P.J. and A. Liu (2012): Consumer behaviour towards honey products in Western Australia. British Food Journal 114, 285-297.

Bernardoni, P., Leonetti, L. and K. Rama (2018): Project "BiodivBalkans - Conservation et valorisation de la biodiversité: Développement durable de la montagne balkanique". Final evaluation report, Tirana, Albania

Brščić, K., Šugar, T. and D. Poljuha (2017): An empirical examination of consumer preferences for honey in Croatia. Applied Economics 49, 5877-5889.

Bytyqi, N., Skreli, E., Verçuni, A., Imami, D. and E. Zhllima (2015): Analyzing consumers' preferences for apples in Pristina, Kosovo. Die Bodenkultur: Journal of Land Management, Food and Environment 66, 61-69.

Cattin, P. and D.R. Wittink (1982): Commercial use of conjoint analysis: A survey. Journal of Marketing 46, 44-53.

Chan-Halbrendt, C., Zhllima, E., Sisior, G., Imami, D. and L. Leonetti (2010): Consumer preferences for olive oil in Tirana, Albania. International Food and Agribusiness Management Review 13, 1-13.

Chrzan, K. and B. Orme (2000): An overview and comparison of design strategies for choice-based conjoint analysis. Research Paper Series, Sawtooth software, Inc., Sequim, WA, USA, 19 pp.

Cicia, G., Del Giudice, T. and R. Scarpa (2002): Consumers' perception of quality in organic food: a random utility model under preference heterogeneity and choice correlation from rank-orderings. British Food Journal 104, 200-213.

Ćirić, M., Ignjatijević, S. and D. Cvijanović (2015): Research of honey consumers' behavior in province vojvodina. Economics of Agriculture 62, 627-644.

Cosmina, M., Gallenti, G., Marangon, F. and S. Troiano (2016): Attitudes towards honey among Italian consumers: A choice experiment approach. Appetite 99, $110-58$.

Ghorbani, M. and N. Khajehroshanaee (2009): The study of qualitative factors influencing on honey consumers demand: application of hedonic pricing model in Khorasan Razavi province. Journal of Applied Sciences 9, 1597-1600.

Green, P.E. (1975): New Ways to Measure Consumers' Judgements. Harvard Business Review 53, 107-117. 
Gyau, A., Akalakou, C., Degrande, A. and A. Biloso (2014): Determinants of consumer preferences for honey in the Democratic Republic of Congo. Journal of Food Products Marketing 20, 476-490.

Halbrendt, C.K., Wirth, F.F. and G.F. Vaughn (1991): Conjoint analysis of the Mid-Atlantic food-fish market for farm-raised hybrid striped bass. Journal of Agricultural and Applied Economics 23, 155-163.

Hensher, D.A. (1994): Stated preference analysis of travel choices: The state of practice. Transportation 21, 107 133.

Imami, D., Zhllima, E., Canavari, M. and E. Merkaj (2013). Segmenting Albanian consumers according to olive oil quality perception and purchasing habits. Agricultural Economics Review 14, 97-117.

Imami, D., Skreli, E., Zhllima, E., Cela, A. and O. Sokoli (2015): Consumer preferences for typical local products in Albania. Economia Agro-Alimentare 17, 11-29.

Imami, D., Skreli, E., Zhllima, E. and C. Chanb (2017): Consumer attitudes towards organic food in the Western Balkans-the case of Albania. Economia Agro-Alimentare 19, 243-257.

INSTAT (Albanian Institute of Statistics) (2012): Census of Population and Housing 2011. http://www.instat. gov.al/en/census/census-2011/census-data.aspx.

INSTAT (Albanian Institute of Statistics) (2016): Agriculture Statistics 2015. http://www.instat.gov.al/en/ themes/agriculture,-forestry-and-fishery/publications/ books/2016/press-release-agriculture-statistics-2015. aspx.

Judd, V.C. (2000): The price-quality relationship: An empirical study of food products. Journal of Food Products Marketing 6, 11-24.

Juma, C. N., Otieno, D. J., Oluouch-Kosura, W., Gyau, A. and J.A. Oduol (2016): A survey of consumer perceptions and preferences for geographical indication and quality attributes of honey in Kenya. African Association of Agricultural Economists (AAAE), $5^{\text {th }}$ International Conference, 23-26 September 2016, Addis Ababa, Ethiopia.

Kaškoniené, V. and P.R. Venskutonis (2010): Floral markers in honey of various botanical and geographic origins: a review. Comprehensive Reviews in Food Science and Food Safety 9, 620-634.

Kos Skubic, M., Erjavec, K. and M. Klopčič (2018): Consumer preferences regarding national and EU quality labels for cheese, ham and honey: The case of Slovenia. British Food Journal 120, 650-664.
Kowalczuk, I., Jeżewska-Zychowicz, M. and J. Trafiałek (2017): Conditions of honey consumption in selected regions of Poland. Acta Scientiarum Polonorum Technologia Alimentaria 16, 101-112.

Lancaster, K.J. (1966): A new approach to consumer theory. Journal of Political Economy 74, 132-157.

Louviere, J.J. and G. Woodworth (1983): Design and analysis of simulated consumer choice or allocation experiments: an approach based on aggregate data. Journal of Marketing Research 20, 350-367.

MARDWA (2014): Inter-Sectorial Strategy for Agriculture and Rural Development in Albania. Council of Minister's decision No. 709, 29.10.2014.

Mtimet, N., Kashiwagi, K., Zaibet, L. and N. Masakazu (2008): Exploring Japanese olive oil consumer behavior. European Association of Agricultural Economists, International Congress, 26-29 August 2008, Ghent, Belgium.

Murphy, M., Cowan, C., Henchion, M. and S. O'Reilly (2000): Irish consumer preferences for honey: a conjoint approach. British Food Journal 102, 585-598.

Pidek, A. (2001): Youth preferences in honey consumption. Journal of Apicultural Science, 45, 115-119.

Pocol, C.B. and L.A. Mărghitaș (2007): Market study about honey consumption in Romania. Bulletin of University of Agricultural Sciences and Veterinary Medicine Cluj-Napoca. Animal Science and Biotechnologies, 191-194.

Šánová, P., Svobodová, J., Hrubcová, B. and P. Šeráková (2017): Segmentation of honey buyers' behaviour by conjoint analysis. Scientia Agriculturae Bohemica 48, $55-62$.

Scarpa, R. and T. Del Giudice (2004): Market segmentation via mixed logit: Extra-virgin olive oil in urban Italy. Journal of Agricultural \& Food Industrial Organization 2, 141-160.

Skreli, E., Imami, D., Chan, C., Canavari, M., Zhllima, E. and E. Pire (2017): Assessing consumer preferences and willingness to pay for organic tomatoes in Albania: A conjoint choice experiment study. Spanish Journal of Agricultural Research 15, e0114.

Thrasivoulou, A., Manikis, J. and S. Gounari (2000): An evaluation of consumer's preferences on honey quality. Apiacta 35, 121-125.

UNSTAT (2016) Comtrade International trade database. https://comtrade.un.org/data/

Völckner, F. and J. Hofmann (2007): The price-perceived quality relationship: A meta-analytic review and assess- 
ment of its determinants. Marketing Letters 18, 181196.

Ványi, G.Á., Csapó, Z. and L. Kárpáti (2011): Evaluation of consumers' honey purchase habits in Hungary. Journal of Food Products Marketing 17, 227-240.

Wu, S., Fooks, J.R., Messer, K.D. and D. Delaney (2015): Consumer demand for local honey. Applied Economics 47, 4377-4394.

Yeow, S.H.C., Chin, S.T.S., Yeow, J.A. and K.S. Tan (2013): Consumer purchase intentions and honey related products. Journal of Marketing Research \& Case Studies 2013, 197440.
Zhllima, E., Imami, D., Wehinger, T., Zvyagintsev, D. and J. Möllers (2016): Farm diversification in Albania has it a potential to reduce rural unemployment? Rural Labor in Transition: Structural Change, Migration and Governance. IAMO Forum 2016, 22-24 June 2016, Halle (Saale), Germany.

Zhllima, E., Chan-Halbrendt, C., Zhang, Q., Imami, D., Long, R., Leonetti, L. and M. Canavari (2012): Latent class analysis of consumer preferences for wine in Tirana, Albania. Journal of International Food \& Agribusiness Marketing 24, 321-338. 